NBER WORK ING PAPER SERIES

\title{
INTEREST RATE DETERMINATION IN DEVELOPING COUNTRIES: \\ A CONCEPTUAL FRAMEWORK
}

Sebastian Edwards

Mohsin S. Khan

Working Paper No. 1531

\author{
NATIONAL BUREAU OF ECONOMIC RESEARCH \\ 1050 Massachusetts Avenue \\ Cambridge, MA 02138 \\ January 1985
}

This paper was written while the first author was a consultant in the Research Department of the International Monetary Fund in the summer of 1984. The research reported here is part of the NBER's research program in International Studies and project in

Productivity (World Economy). Any opinions expressed are those of the authors and not those of the National Bureau of Economic Research. 
NBER Working Paper \#1531

January 1985

Interest Rate Determination in

Developing Countries:

A Conceptual Framework

ABSTRACT

As a number of developing countries move towards more liberalized financial systems, the question of how interest rates respond to foreign influences and domestic policies is one that policymakers in these countries have started to face. Most existing studies of interest rates typically treat only the extreme cases of either a fully open economy, where some form of interest rate arbitrage holds, or a completely closed economy, in which interest rates are determined solely by domestic monetary factors. Developing countries, however, generally fall somewhere between these two extremes, so that the standard models of interest rate determination would not seem to be relevant to their case.

The purpose of this paper is to outline a theoretical framework that can serve as a starting point for analyzing interest rate determination in those developing countries that are in the process of removing controls on the financial sector and restrictions on capital flows. The approach suggested here combines elements of the closed-economy and open-economy models, and thus is able to incorporate the influences of foreign interest rates, expected changes in exchange rates, and monetary developments on domestic interest rates. An interesting feature of the resulting model is that the approximate degree of financial openness, defined as the extent to which domestic interest rates are linked to foreign interest rates, can in fact be ascertained from the data of the particular country.

To illustrate the empirical validity of the proposed model it was applied to two countries -- Colombia and Singapore. These two countries are quite different in terms of levels of financial development and degrees of openness, and thus provide a useful first test of the general nature of the model. The model is able to represent both these cases quite adequately. The estimates indicate that in Colombia both foreign and domestic factors are important, while domestic interest rates in singapore are fully determined by foreign interest rates and variations in the exchange rate. This is precisely what would have been expected, given the characteristics of the respective Einancial systems in the two countries.

Sebastian Edwards Department of Economics UCLA

Los Angeles, CA 90024

(213) 825-1011
Mohsin S. Khan

Research Department

International Monetary Fund

Washington, D.C. 20431

(202) $473-7679$ 
Revised Draft

November 27,1984

Interest Rate Determination in Developing Countries:

A Conceptual Framework

by

Sebastian Edwards and Mohsin S. Khan*

\section{Introduction}

During the last decade or so economists have emphasized the critical role that interest rate policies play in the development process. The growing literature on financial "reform" and financial "liberalization" in developing countries has dealt with a variety of issues, such as the relation between financial intermediation and economic growth, the sensitivity of the volume of savings to changes in real interest rates, and the relation between investment and interest rates. Generally speaking, the empirical evidence indicates that there is indeed a positive association between the degree of development of the financial sector, including in particular freer interest rates, and economic performance in developing countries. 1/ This finding has undoubtedly prompted the authorities in a number of such countries to pursue policies to remove controls on interest rates, and allow market forces to play a relatively greater role in their determination.

Now, however, that the process of financial liberalization is well underway, economists and policymakers are faced with a different set of issues relating to interest rates in developing countries. The focus has

* The authors are grateful to a number of colleagues for comments on an earlier draft. Abdel R. Ismael provided very helpful assistance.

$1 /$ See, for example, McKinnon (1973), Fry (1982), Lanyi and Saracoglu (1983), Mathieson (1983), and Townsend (1983). 
begun to shift away from investigating the effects of freeing interest rates to how interest rates are in fact determined once the domestic Einancial market has been liberalized. The interest in this particular issue has been heightened by two factors. First, the recent experiences of the Southern Cone countries--Argentina, Chile, and Uruguay--where domestic interest rates rose to extraordinary high levels following the implementation of fiñancial reform policies. $1 /$ Second, the evidence that has accumulated suggesting that the high and volatile world interest rates in recent years were at least partially transmitted into developing countries. Both these factors have been a cause of concern to policymakers and have generated some very basic questions about the behavior of interest rates in developing countries, and in particular what should be expected when controls on interest rates are eliminated. At present, however, there are few studies dealing with this general issue, and even fewer specifically examining the respective roles of foreign factors and domestic monetary conditions in affecting interest rates in developing countries. $2 /$

It is obvious that the process of determination of interest rates will be significantly different under alternative degrees of openness of the capital account of the balance of payments. For example, in the case of a fully open capital account some form of interest arbitrage will hold, with domestic interest rates depending on world interest rates, expected devaluation and perhaps some risk factors. On the other hand, in

1/ See, for example, Diaz-Alejandro (1981), Edwards (1985a), Hanson and de Melo (1984), Harberger (1982), Sjaastad (1983), and Zahler (1983).

$2 /$ The only studies we are aware of that include both open-economy and domestic monetary factors in the analysis of interest rates are Mathieson (1982), (1983) on Argentina and Chile respectively, Blejer and Gil Diaz (1984) and Hanson and de Melo (1984) on Uruguay, and Edwards (1985b) on Colombia. 
the case of countries with a completely closed economy (closed capital and current accounts), open economy factors will play no role, and the nominal interest rate will be determined by conditions prevailing in the domestic money market, and on expected inflation. Most developing countries, however, do not fall in either of these two extreme categories, so that interest rates will generally depend on domestic money market conditions, as well as on the expected rate of devaluation and world interest rates. I/ From a policy perspective it is important to determine the way these different factors actually affect interest rates. For example, how expected devaluations and/or changes in domestic monetary conditions affect interest rates in developing countries is important for assessing the significance of one of the possible mechanisms through which stabilization policies will affect aggregate demand. Typically, stabilization programs involve both exchange rate adjustments and tighter credit and monetary policies. If these policles generate an increase in the domestic (real) interest rate, there will be an additional channel, which has usually not been considered in formal studies on stabilization programs in developing countries, through which aggregate demand will be affected. $\underline{2}$ /

1/ Even in the case where the capital account of the balance of payments is closed, but there is some trade with the rest of the world, open economy factors can still indirectly affect domestic interest rates. For example, a terms of trade shock can result in changes in real income and prices, which will affect the domestic demand for credit, and thus equilibrium interest rates.

2/ Until now most studies that have analyzed the effect of stabilization policies on output, prices and the balance of payments in developing countries have not included the interest rate as a possible transmission mechanism. The main reas on for this is that the experience with liberalized capital markets is still relatively recent. A theoretical discussion, however, of the effects of a stabilization program working through increases in real interest rates is contained in Dornbusch (1982b). 
In this paper a framework for empirically analyzing the determination of nominal interest rates in developing countries is proposed: Even though the model is quite general and of relevance for any small country, the discussion is carried out with the case of those developing countries in mind that have liberalized their domestic financial sector, in the sense of having removed controls on interest rates. The model, which is described in Section II, combines closed- and open-econony features, and it is shown that the relative importance of the domestic monetary conditions and the open economy factors will depend essentially on the openness of the capital account. An interesting property of the model is that the approximate degree of openness of the financial sector in a particular country can be estimated from the data. In Section III of the paper the usefulness of this framework for analyzing interest rate behavior is illustrated using data for Colombia and Singapore. The results obtained indicate that, as expected, in Singapore only open economy factors appear to matter; in Colombia, on the other hand, both domestic monetary disquilibria and open economy conditions have influenced nominal interest rates during the last fifteen years. Section IV describes some areas in which the analysis could be extended, including, for example, analyzing the behavior of real interest rates, the determination of interest rates under changing degrees of openness, the modelling of the effects of expected exchange rate changes, and finally taking into account the role of currency substitution. The concluding section summarizes the main ideas and results of this paper. 
II. Theoretical Models of Interest Rate Determination

In this section three basic models for analyzing interest rate behavior in developing economies are briefly presented. First, we describe a simple model that assumes that the country in question is completely closed to the rest of the world. Under these circumstances it is assumed that the nominal interest rate depends on the real interest rate and on expected inflation. The second model considers the other extreme where the capital account is completely open. In this case domestic interest rates are closely linked to world interest rates through the interest arbitrage condition. Finally a more general model that allows both foreign and domestic factors to affect the behavior of the nominal interest rate, and thus contains the other two models as special cases, is presented and discussed.

1. Interest rates in a closed economy Following the standard Fisher approach, the nominal interest rate can be specified as equal to: 1/

$$
\text { (1) } i_{t}=r r_{t}+\pi_{t}^{e}
$$

where,

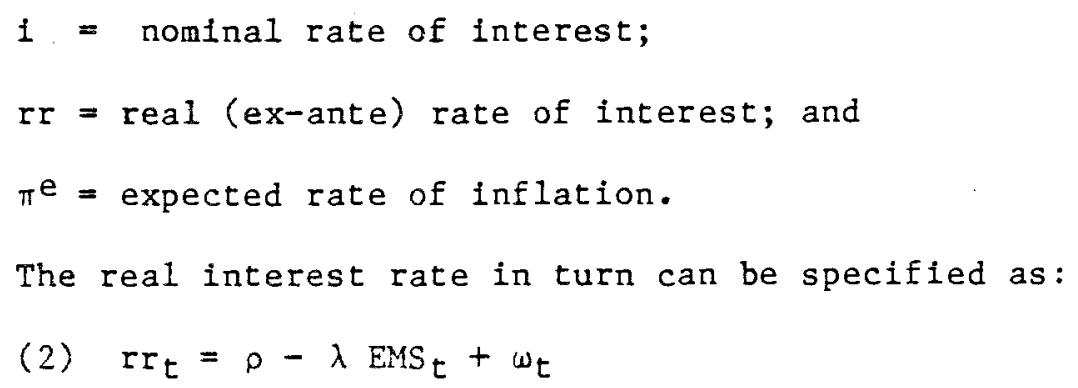


where $\rho$ is a constant, and represents the long-run equilibrium real interest rate. The variable EMS represents the excess supply for money, $\lambda$ is a parameter $(\lambda>0)$, and $\omega_{t}$ a random error term. According to equation (2) the real rate of interest would deviate from its long-run value $\rho$ if there is monetary disequilibrium; an excess demand (supply) for real money balances will result in a temporarily higher (lower) real interest rate. This relationship has been termed the "liquidity effect" in the literature (Munde1l (1963)). In the long run, however, the money market would be in equilibrium and the variable EMS would play no role in the behavior of $\mathrm{rr}_{\mathrm{t}} \cdot \underline{1 /}$ Introducing this liquidity effect into the model, contrary to most recent empirical studies of interest rate behavior, allows the real rate of interest to be variable in the short-run. $\underline{2}$ As such, even though the Fisher equation (1) is assumed to hold continuously, the possibility of slow adjustment of the real interest rate (given by d) implicitly allows for the possibility of delayed response of the nominal interest rate to monetary changes.

The solution for the nominal interest rate in a closed economy is therefore:

$$
\text { (3) } i_{t}=\rho-\lambda E M S_{t}+\pi_{t}^{e}+\omega_{t}
$$

In order to estimate equation (3), however, some assumptions have to be made regarding the unobserved variables, such as $\pi^{e}$ and EMS. The expected rate of inflation can be specified in a variety of ways. One

\footnotetext{
$1 /$ Note that more generally EMS $t$ could also affect $\pi_{t}^{e}$. Furthermore, it is assumed here that changes in $\pi_{t} e^{-}$have no direct effects on $\mathrm{rr}_{t}$. on these types of effects see Mundell (1963).

2/ For recent empirical studies on interest rates behavior in the U.S. see, for example, Fama (1975), Tanzi (1980), Makin (1982), and Melvin (1983).
} 
way is to utilize the traditional adaptive-expectations model, in which the expected rate of inflation is assumed to be a (geometrically) distributed lag function of past rates of inflation. An empirical generalization of this approach is to assume an autoregressive process for the rate of inflation, and use the predicted values as representing the expected rate of inflation. 1/ Other possible methods include the use of survey data, $2 f$ or models that allow for the influence of additional economic variables other than only past rates of inflation in the formation of expectations. $\underline{3} /$ of course, it can also be assumed that actual and expected rates of inflation are the same, which would imply a strict form of rational expectations (i.e., perfect foresight). There is really no compelling theoretical reason for preferring one method over any other, and the choice is ultimately an empirical one.

The excess supply of money is defined as:

(4) EMS $_{t}=\log m_{t}-\log m_{t}^{d}$

where $m$ is the actual stock, and $\mathrm{m}^{\mathrm{d}}$ the desired equilibrium stock, of real money balances. 4/ In an economy which has completed the financial reform process we would expect substitution to take place between both money and

1/ In this formulation the weights of the lag distribution are not assumed to follow any specific pattern.

2/ For example, the Livingston series on inflationary expectations.

3/ These would be the empirical representations of the rational expectations model in which economic agents are assumed to take into account all available information in forming their (conditional) expectations.

4/ It should be noted that equation (4) is only one of the alternative ways to specify excess money supply, or monetary disequilibrium. For example, it can be postulated that only money surprises will influence the real interest rate, (Makin (1982)). In such a case EMS would have to be replaced by some measure of unanticipated monetary changes in equation (2). 
goods, as well as money and financial assets, so that the demand for money would be a function of two opportunity cost variables, namely the expected rate of inflation and the rate of interest, along with a scale variable (real income). 1/ The equilibrium demand for money can therefore be written as:

(5) $\quad \log m_{t}^{d}=\alpha_{0}+\alpha_{1} \log _{t}-\alpha_{2}\left(\rho+\pi_{t}^{e}\right)-\alpha_{3} \pi_{t}^{e}$

It should be noted that long-run demand for money is assumed to be a function of the equilibrium nominal interest rate, defined as the equilibrium real interest rate $(p)$ plus the expected rate of inflation, rather than the current nominal interest rate.

The model can be closed by assuming that the stock of real money balances adjusts according to:

(6) $\Delta \operatorname{logm}_{t}=\beta\left[\operatorname{logm}_{t}^{d}-\log m_{t-1}\right]$

where $\Delta$ is a first-difference operator, $\Delta \log _{t}=\log m_{t}-\log m_{t-1}$, and $B$ is the coefficient of adjustment, $0<B<1$. If the nominal stock of money is exogenous, then equation (6) really describes an adjustment mechanism for domestic prices. Basically, equation (6) introduces a process through which the nominal interest rate returns eventually to its equilibrium level.

The workings of the model given by equations (3), (4), and (6), can be conveniently described within the framework of Figure 1 . In this figure the initial equilibrium is point $A$ where the long-run demand for real money balances is equal to the supply (EMS $=0$ ), the nominal interest

\footnotetext{
If of course, one could also introduce an "own". rate of return into the money demand formulation. This would certainly be advisable when dealing with broad definitions of money that include deposits paying positive rates of interest (see Mathieson (1982), (1983)). In our case, however, since we work with narrow money (currency plus demand deposits) throughout, this omission is obviously not serious, as demand deposits are typically non-interest bearing.
} 
FIGURE 1

INTEREST RATE DETERMINATION:

CLOSED ECONOMY

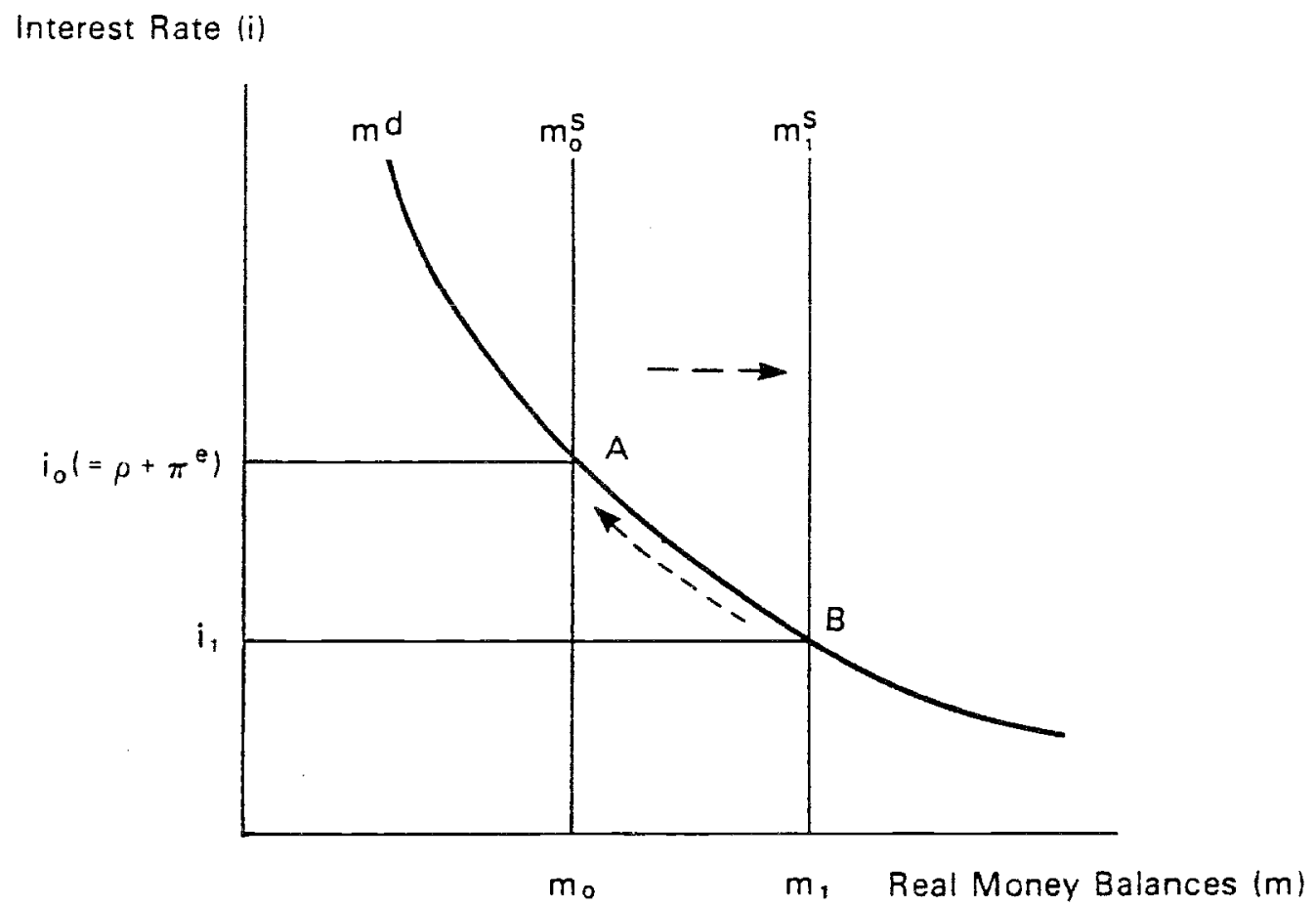


rate is at its equilibrium level $\left(\rho+\pi^{e}\right)$, and the actual stock of real money balances is equal to $m_{0}$. Suppose now that there is an increase in the supply of money from $\mathrm{m}_{0}^{\mathrm{s}}$ to $\mathrm{m}_{1}^{\mathrm{s}}$. This would create an excess supply of real money balances (EMS $>0$ ), and the nominal interest rate would fall below its equilibrium value (say to $i_{1}$ ). The movement from A to $B$ essentially represents the short-run liquidity effect we referred to earlier. However, $B$ is only a temporary equilibrium position, since in the next period the (unchanged) long-run demand for money is less than the actual stock in the previous period, $\mathrm{m}_{t+1}^{d}<\mathrm{m}_{t}\left(\mathrm{~m}_{2}^{s}\right)$, and therefore by equation (6), the actual stock of real money balances would begin to decline. In Figure 1 the $\mathrm{m}^{\mathrm{s}}$ schedule would shift to the left until the actual money supply is once again equal to the equilibrium money demand, and consequently the nominal interest rate would be given by $0+\pi^{e}$.

Equation (6) can be simplified to:

$$
\text { (6a) } \log _{t}=\beta \log \mathbb{m}_{t}^{d}+(1-\beta) \log m_{t-1}
$$

and combining equations ( 4 ) and (6a) we obtain:

$$
\text { (7) } \text { ElS }_{t}=(1-\beta)\left[\operatorname{logm}_{t-1}-\log _{t}^{d}\right]
$$

Using equations ( 1$),(5)$, and ( 7 ) we can derive the reduced-form equation for the nominal interest rate:

$$
\text { (8) } 1_{t}=\gamma_{0}+\gamma_{1} \log _{t}+\gamma_{2} \operatorname{logm}_{t-1}+\gamma_{3} \pi_{t}^{e}+\omega_{t}
$$

where the composite parameters are:

$$
\begin{aligned}
& r_{0}=p+\lambda(1-\beta)\left(\alpha_{0}-\alpha_{2} p\right) \\
& r_{1}=\lambda(1-\beta) \alpha_{1} \\
& r_{2}=-\lambda(1-\beta) \\
& r_{3}=\left[1-\lambda(1-\beta)\left(\alpha_{2}+\alpha_{3}\right)\right]
\end{aligned}
$$


Once $\pi^{e}$ is replaced by some appropriate measured variable, equation (9) can be directly estimated. In the estimation it would be expected that $\gamma_{1}>0$, and $\gamma_{2}<0$; the sign of $\gamma_{3}$ would be negative or positive depending on whether $\lambda(1-\beta)\left(\alpha_{2}+\alpha_{3}\right)$ is greater or less than one.

\section{Interest rates in a fully open economy}

If the economy is completely open to the rest of the world, and there are no impediments to capital flows, domestic and foreign interest rates will be closely linked. In particular in a world with no transaction costs and risk neutral agents the following uncovered interest arbitrage relation will hold:

$$
\text { (9) } \dot{1}_{t}=\dot{1}_{t}^{*}+\dot{e}_{t}
$$

where it is the world interest rate for a financial asset of the same characteristics (maturity and so on) as the domestic instrument, and $\dot{e}_{t}$ is the expected rate of change of the exchange rate. $1 /$ If, however, agents are assumed to be risk averse $\dot{e}_{t}$ should be replaced by the forward premium, or alternatively, a (time-varying) risk premium term should be added to equation (9).

Usually the analysis of interest rate behavior in open economies has amounted to Investigating the extent to which (9), or some variant of it, holds. One way of doing this is by adding transaction costs and defining a band within which the interest parity differential can vary, without violating the arbitrage condition. Another way of testing equation (9) is through the analysis of the time series properties of the interest 
parity differential. If these time series are not serially correlated, i.e., they are white noise, it is usually concluded that the donestic interest rate depends only on open economy factors. $1 /$ Frenkel and Levich (1975, 1977), for example, have analyzed the extent to which the covered arbitrage condition, which replaces $\dot{e}_{t}$ by the forward premium in (9), held for industrialized countries during the period following the adoption of floating rates in 1973. They showed that once transaction costs are allowed into the analysis, this arbitrage condition has worked well for these countries. Using a similar methodology, Lizondo (1983), on the other hand found evidence of large and persistent deviations in the case of Mexico during 1979-80. Cumby and Obstfeld (1981) adopted the second of the two approaches and analyzed the time series properties of the uncovered interest arbitrage differential using weekly data for six industrialized countries, and found that, in five of the six cases, these series exhibited strong serial correlation. They interpret these results as providing evidence that there exists a (time varying) foreignexchange premium for most currencies. $2 /$ The tests performed by Blejer (1982) using monthly data for Argentina for June 1977-August 1981, however, could not reject the hypothesis that the uncovered interest rate differential

\footnotetext{
1/ However, from a methodological point of view, even if interest parity arbitrage differentials are white noise it is still possible that other variables, besides the world interest rate and the expected rate of devaluation, will affect the domestic interest rate. For this reason a more appropriate procedure is to directly test whether other variables suggested by the theory have an effect on $i_{t}$. 2/ See Levich (1984) for a review on other studies that have dealt with rêtated issues.
} 
was white noise for Argentina during this period. 1/ Broadly speaking, the evidence appears fairly mixed on the interest parity condition in open economies.

There, of course, exists the possibility that due to frictions arising from transactions costs, information lags, etc., that domestic interest rates respond with delay to any changes in the foreign rate of interest or in exchange rate expectations. This type of lagged response can be mode1led straightforwardly in a partial-adjustment framework as follows:

$$
\text { (10) } \Delta i_{t}=\theta\left[\left(i_{t}^{*}+\dot{e}_{t}\right)-i_{t-1}\right]
$$

where $\theta$ is the adjustment parameter, $0 \leq \theta \leq 1$. If the financial market adjusts very rapidly this parameter $\theta$ will tend towards unity. Conversely, a small value of $\theta$ would imply slow adjustment of the domestic interest rate. $2 /$ The solution of equation (10) in terms of the domestic interest rate is:

$$
\text { (11) } i_{t}=\theta\left(i_{t}^{*}+\dot{e}_{t}\right)+(1-\theta) i_{t-1}
$$

\section{The general case}

The preceding discussion has dealt with interest rate determination in the two polar cases regarding the degree of openness of the economy. If, however, the economy under consideration is one that has some controls

1/ In a more recent study for Uruguay, Blejer and Gil Diaz (1984) found that the risk premium was highly serially correlated.

2/ During the period when the parity condition does not exactly hold there would obviously be unexploited profit opportunities. The attempts by transactors to take advantange of these opportunities would set in motion the very forces that would bring about equality between domestic and foreign interest rates (adjusted for expected exchange rate changes). How long this process takes is an empirical question and would have to be estimated from the data. 
on capital movements, as most developing countries do, it is possible to visualize that, at least in the short-run, both open and closed economy factors will affect the behavior of domestic interest rates. A straightforward way of constructing a model for such an economy is to combine the closed economy and open economy extremes. In particular, it can be assumed that the equation for the nominal interest rate can be specified as a weighted average, or linear combination, of the open and closed economy expressions discussed above. Denoting the weights by $\psi$ and( $1-\psi)$ and combining equations ( 1 ) and ( 9 ), the following model for the nominal interest rate can be specified:

(12) $i_{t}=\psi\left(i_{t}^{*}+\dot{e}_{t}\right)+(1-\psi)\left(\operatorname{rr}_{t}+\pi_{t}^{e}\right)$

where the parameter $\psi$ can be interpreted as an index measuring the degree of financial openness of the country. If $\psi=1$ the economy is fully open and equation (12) collapses into the interest arbitrage condition (9). If, on the other hand, $\psi=0$ the capital account is closed and equation (12) becomes equal to the Fisher closed-economy equation (1). In the intermediate case of a semi-open (semi-closed) economy the parameter $\psi$ will lie between zero and one; the closer it is to one the more open the economy will be. In some sense by estimating $\psi$ from the data it is possible to determine the degree of openness of the financial sector in a particular country. This estimated degree of openness will provide some information on the actual degree of integration of the domestic capital market to the world financial market. To the extent that official capital and exchange controls are not fully effective, the empirically 
estimated "economic" degree of openness can be significantly higher than the "legal" degree of openness implied by the system of capital controls in the country. $1 /$

If we assume slow adjustment to interest parity and thus use equation (11) instead of equation (9), the appropriate form for the general case becomes:

$$
\dot{i}_{t}=\psi \theta\left(i_{t}^{*}+\dot{e}_{t}\right)+\psi(1-\theta) i_{t-1}+(1-\psi)\left(r r_{t}+\pi_{t}^{e}\right)
$$

In this case full interest parity would require the condition $\psi=\theta=1$; when $\psi=0$ the Fisher closed-economy condition would emerge. It should be noted that there will be some relation between the index of financial openness, $\psi$, and the speed of adjustment, $\theta$. For example, if the domestic financial market is fully integrated with the international capital markets it is also likely that domestic interest rates would adjust very rapidly.

Assuming that the excess money supply term is given by equation (4), and that the demand for real money function by equation (5), we obtain from (13) the following expression for the nominal interest rate: $2 /$

$$
\text { (14) } \begin{aligned}
i_{t} & =\delta_{0}+\delta_{1}\left(i t+\dot{e}_{t}\right)+\delta_{2} \log y_{t}+\delta_{3} \log \mathrm{m}_{t-1} \\
+ & \delta_{4} \pi_{t}^{e}+\delta_{5} i_{t-1}+\varepsilon_{t}
\end{aligned}
$$

where the reduced-form parameters $\delta_{i}$ are:

$$
\begin{aligned}
& \delta_{0}=(1-\psi)\left[\rho+\lambda(1-\beta)\left(\alpha_{0}-\alpha_{2} \rho\right)\right. \\
& \delta_{1}=\psi \theta
\end{aligned}
$$

1/ It is, of course, assumed here that the degree of openness ( $\psi$ ) is constant over time. The implications of relaxing this assumption, and the procedures one could adopt to do so, are considered in section IV.

$2 /$ Note that when $\theta=1$ the lagged interest rate term would drop from the specification, so that the equilibrium model is only a restricted version of this formulation. 


$$
\begin{aligned}
& \delta_{2}=(1-\psi) \lambda(1-\beta) \alpha_{1} \\
& \delta_{3}=-(1-\psi) \lambda(1-\beta) \\
& \delta_{4}=(1-\psi)\left[1-\lambda(1-\beta)\left(\alpha_{2}+\alpha_{3}\right)\right] \\
& \delta_{5}=\psi(1-\theta)
\end{aligned}
$$

If we assume that the income elasticity of the demand for money is unity, then the model can be further simplified. In this case $\gamma_{2}=-\gamma_{3}$ and real income and lagged real money balances can be combined into one composite variable, i.e., $\left[\log _{t}-\log _{t-1}\right]$.

Equation (14) is quite general as it not only incorporates open economy and closed economy features, but further permits the possibility of slow adjustment on both the foreign and domestic sides. 1/ One can see that in the case of a completely open economy with instantaneous adjustment of the domestic interest rate (i.e., $\psi=\theta=1.0$ ), $\delta_{1}$ becomes equal to 1.0 and $\delta_{0}=\delta_{2}=\delta_{3}=\delta_{4}=\delta_{5}=0$. According to equation (14) the nominal interest rate will then be equal, both in the long- and short-run, to $\left(i+\dot{e}_{t}\right)$. In the case of a completely closed economy $(\psi=0)$ the parameters $\delta_{1}$ and $\delta_{5}$ will be equal to zero, and equation (14) collapses to the closed economy equation ( 8 ).

The preceding discussion has assumed that agents are risk neutral. However, as mentioned, if agents are risk averse equation (14) should be modified to take this fact into account. The simplest way of doing this is by replacing the expected rate of devaluation $\dot{e}_{t}$ by the forward

\footnotetext{
1/ It should be noted that an equation of the form of (14) can be derived from a portfolio model with imperfect substitutability between domestic and foreign assets.
} 
premium. From a practical viewpoint, however, this poses difficulties since there are very few developing countries which have forward markets for their currencies. An alternative way to deal with the risk aversion problem is to explicitly introduce a risk premium into the analysis, and to make some assumptions about its statistical properties. For example, it can be assumed that the risk premium is equal to a constant plus a random term. In this case the constant part of the premium will be added to the constant in equation (14), while the random component becomes a part of the error term. In principle, it would be possible to incorporate any number of alternative assumptions regarding the behavior of the risk premium into the empirical analysis. $1 /$

III. Empirical Tests of the Model of Interest Rate Determination To assess, the ability of the general model to describe the process of interest rate determination in developing countries, it was estimated using quarterly data for Colombia and Singapore. Since these two countries are quite different, both in terms of the development of their domestic financial markets as well as in the degrees of controls over capital flows, they should provide a fair test of the basic model. As both countries are open in varying degrees it would have been preferable to round out the picture by including an example of a closed economy as well in the analysis. For obvious reasons this was not possible. $\underline{2}$ /

\footnotetext{
I/ Notice that the present formulation also ignores the presence of poIitical risk factors.

2) First of all there are few developing countries that can be viewed as completely closed, and second, those that would qualify do not have developed financial systens with market-determined interest rates.
} 
Since 1967 Colombia has basically followed a growth strategy based on export promotion. During the last fifteen years a crawling-peg exchange rate system has been in effect, and at least in a segment of the capital market interest rates have been allowed to fluctuate freely. $1 /$ Over this period the domestic capital market was slowly liberalized, but a number of restrictions to capital movements were maintained. For example, there were restrictions on the minimum maturity of loans obtained from abroad (usually 5 years); the movement of capital in and out of the country required formal approval from a number of government agencies, including the Exchange office, the Ministry of Finance, and the National Planning Department; and there was a 95 percent advance payment deposit on all capital outflows. 2/ While there was some capital mobility the existence of such legal restrictions make it best for practical purposes to characterize Colombia as a semi-open economy rather than fully open. As such in terms of our model we would expect to obtain a positive value for the openness parameter $\psi$, and a value of $\theta$ of less than unity. On the other hand, the Singapore economy can be regarded as highly open, with virtually no restrictions on trade and capital flows. $3 /$ For

\footnotetext{
1/ See Diaz-Alejandro (1976), Wiesner (1980), and Montes and Candelo (19)82).

2/ See IMF, Annual Report on Exchange Restrictions, for a detailed description of the nature and extent of capital controls in Colombia. 3/ See Blejer and Khan (1983).
} 
example, imports are mostly unrestricted, with a very small number subject to tariffs, and all payments can be made freely. As far as the capital account is concerned, the last elements of exchange controls were eliminated in June 1978, and there are no hindrances to the movement of capital. $1 /$ After being pegged to sterling, the Singapore dollar floated from June 1973 to late 1975. From then on the currency has been pegged to a trade-weighted basket of the currencies of its major trading partners. The floating of the Singapore dollar led to a rapid development of the foreign exchange market, and although the volume of transactions is not as large as in the major financial centers, the Singapore market has over the years become the largest in developing countries. A very active forward market, covering transactions of various maturities, has also developed, with quotations being given on a daily basis by participating banks. In general, the progressive freeing of financial transactions, the exchange rate policy, and direct encouragement by the government through its financial development program, have combined to make Singapore into an important financial center with close links to other major financial markets. These institutional factors would lead one to expect that in the case of Singapore the openness parameter, $\psi$, would be close to unity, and that domestic interest rates would respond rapidly to foreign developments, $(\theta=1)$.

If In fact, even prior to 1978 there were no limits on residents investments in the Scheduled Territories (comprising the former Sterling Area). Since Hong Kong was included in the Scheduled Territories, residents could, in theory, transfer funds anywhere via the Hong Kong market, so that this restriction was not particularly effective. 
Equation (14), and its equilibrium variant excluding the lagged interest rate term, were estimated by ordinary least squares for the two countries using quarterly data. For Colombia the data was for the period running from the third quarter of 1968 to the fourth quarter of 1982 , while for Singapore it covers the period from the third quarter of 1976 through the last quarter of 1983. 1/ In the estimation equations for Colombia the expected rate of devaluation between period $t$ and $t+1\left(\dot{e}_{t}\right)$ was replaced by the actual rate of depreciation in period $t$. This assumption implies that during the period under consideration, the rate of devalution in Colombia can be represented approximately as a random walk process with zero drift. $2 /$ Since forward rates are available for the Singapore dollar, we used the forward premium to proxy the expected exchange rate change. It is implicitly assumed in the analysis that the exchange rate risk premium is captured in the constant and error terms. For both countries the expected rate of inflation was calculated by fitting an autoregressive process (with seven lags) to the actual rate of inflation, and then using the predicted values to represent $\pi_{t}^{e} \cdot \underline{3} /$ Finally, for reasons of efficiency, the income elasticity for money was set equal to unity and thus we were able to combine the incone and lagged money variables. 4/ The results for the two countries are shown in Table 1.

1/ See the Appendix for the data sources.

2/ See Edwards (1985a).

$\overline{3} /$ Using the actual rate of inflation (i.e., the perfect foresight model) did not produce any significant differences in the estimations. 4/ This assumption is consistent with independent empirical evidence on the demand for money relationship for both the countries. See, for example, Montes and Candelo (1982) for Colombia, and Khan (1981) for Singapore. 


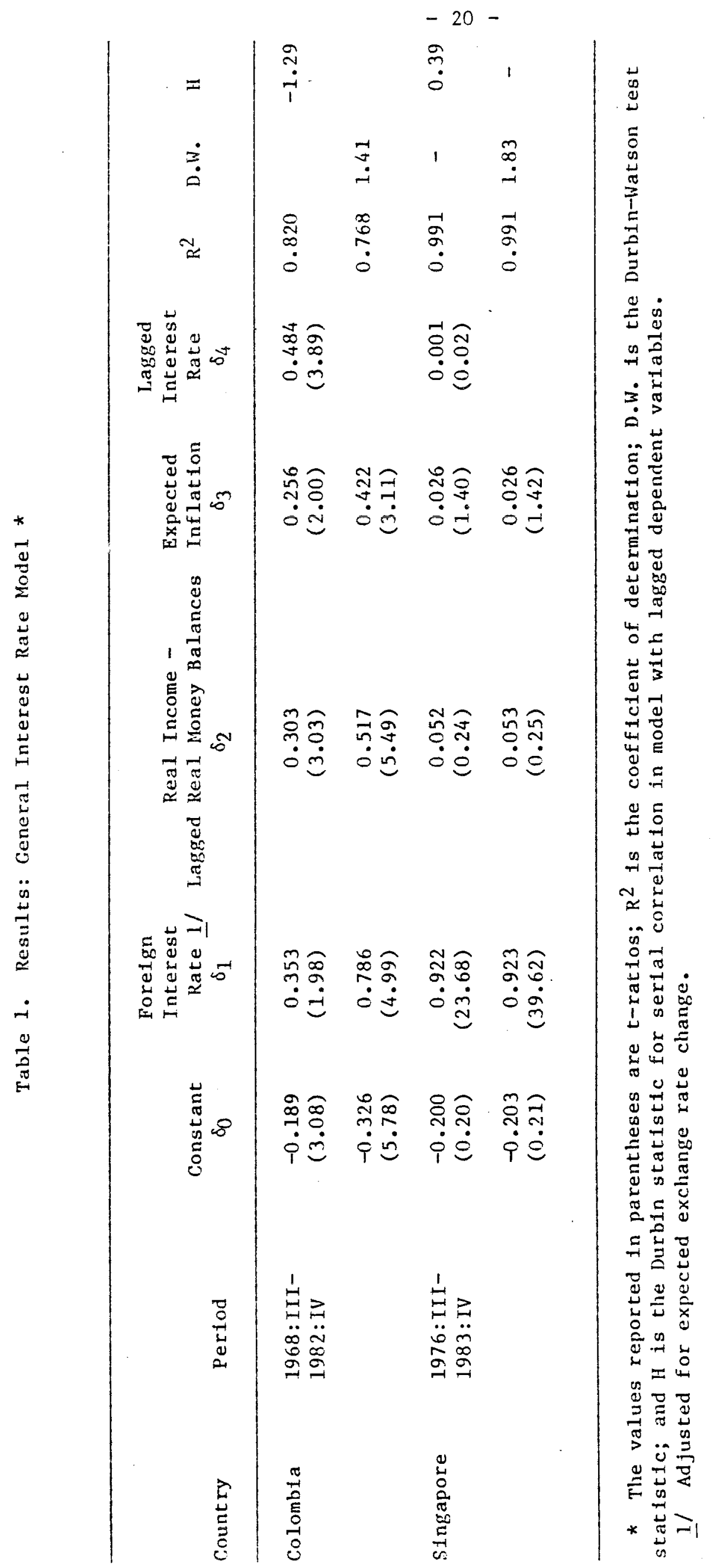


Taking the case of Colombia first, we can see from Table 1 that the results are very satisfactory. All the coefficients have the correct signs and are significant at the conventional levels. I/ In particular, the significance of the coefficients of $\left(i_{t}^{*}+\dot{e}_{t}\right)$ and $\log m_{t-1}$ clearly indicate that the nominal interest rate in Colombia has been sensitive to both foreign and domestic influences, and ignoring either of these factors--as is the case when more traditional approaches to interest rate determination are used--important elements are left out of the story. Since the coefficient of the lagged interest rate is significantly different from zero at the 5 percent level, implying that $\theta$ is significantly different from unity, excluding this variable from the specification could obviously not be warranted. This is borne out by the results where the restricted version of the equation yields a poorer fit.

We further calculated the values of what we regard as the key structural parameters, namely the openness parameter $(\psi)$, and the adjustment parameter for the interest rate $(\theta)$. The value of $\psi$ turns out to be 0.84 (with a t-value of 5.94 ), which is quite high, indicating that the Colombian financial sector has, in practice, been more integrated to the rest of the world than what one might be lead to believe after analyzing the nature and extent of capital controls during this period.

\footnotetext{
If Noting that the sign of the reduced-form coefficient for expected inflation $\left(\gamma_{3}\right)$ was ambiguous, the result in Table 1 indicates that $\lambda(1-\beta)\left(\alpha_{2}+\alpha_{3}\right)<1$.
} 
According to this estimated value of $\psi$, a 10 percentage point increase in the world interest rate, for example, will be translated into an increase of the domestic interest rate of over 8 percentage points in the long run. However, as the coefficient of adjustment ( $\theta$ ) is equal to 0.422 (with a t-value of 2.5 ), this implies that the average, or mean-time, lag in adjustment of the nominal interest rate to a change in either the forelgn interest rate or the exchange rate is between 3 and 4 quarters. The results for Singapore are quite different from those of Colombia, with foreign factors playing the clearly dominant role in the determination of the domestic interest rate. The coefficient of the foreign interest rate and expected exchange rate change, $\delta_{1}$, is not significantly different from unity at the 5 percent level. The remaining coefficients in the equation have the expected signs, but are all statistically insignificant. This result implies that for all intents and purposes the openness parameter $\psi$ is unity, which is a result one would have expected in the case of Singapore. Domestic monetary developments have no direct effect on the interest rate, although it is possible that they still could indirectly through their effect on the forward premium. This particular channel, however, has not been considered here. 1/ Also as the value of $\theta$ is unity, implying that the adjustment of the domestic interest rate is instantaneous and interest parity is maintained continuously, it is clearly a matter of

I/ See Section IV. 
indifference which of the two specifications for Singapore is considered. Both the equations, i.e., with and without the lagged interest rate term, appear equally well-specified.

The results reported above were obtained using the excess supply of real money balances as the appropriate formulation for the monetary disequilibrium term. However, as mentioned earlier, there are other ways in which a monetary disequilibrium could affect nominal interest rates. For example, it has been recently argued that nominal monetary surprises can have a temporary impact on nominal interest rates. $1 /$ In order to investigate this proposition equation (14) was re-estimated replacing $\left[\log _{t}-\log m_{t}^{d}\right]$ in equation (4) by a nominal money surprise variable, defined as the residuals from an equation in which the rate of growth of nominal money was regressed on its lagged values up to seven periods. The results for both countries with this formulation were quite similar to those reported in Table 1.

\section{Limitations and Extensions}

The model presented here has its limitations and can obviously be expanded in several directions. In this section we briefly discuss four possible extensions, namely, (1) the analysis of the determinants of real interest rates in developing countries; (2) the analysis of interest rate behavior during the process of liberalization of the capital account of the balance of payments; (3) the explicit modelling of the expected rate of devaluation in the context of interest rate behavior in open developing countries; and (4) the role of currency substitution. This list is by no 
means exhaustive, and specifically does not incorporate various econometric issues that could arise in estimating a model of interest rate determination. Such issues would include, inter alia, simultaneity, specification of the underlying dynamics, and the proper treatment of the error structure. Here we focus mainly on what we see are the main theoretical extensions.

1. Real interest rates in developing countries

Recently, some studies have empirically analyzed the behavior of real interest rates in industrialized countries, placing special emphasis on whether these rates have tended to be equalized across countries. I/ From a theoretical perspective, even if there are no exchange controls and the capital account is fully open, and further that the nominal arbitrage condition holds, real interest rates can still differ across countries. For example, an expectation of a real depreciation would result in a country having a higher real interest rate than the rest of the world. $2 /$ The framework discussed in this paper can be easily extended to analyze the process of determination of (ex-post and ex-ante) real interest rates. Since the ex-post real interest rate is defined as the nominal rate minus the actual rate of inflation, a simple way of doing this is to add an explicit inflation equation to the model. $3 /$ The resulting two-

\footnotetext{
$\frac{1}{2}$ For example, Cumby and Mishkin (1984).

$\frac{1}{2} /$ On the relation between real exchange rates and real interest rates see Dornbusch (1982b).

3/ Note that the adjustment equation (6) in our model could be interpreted as an inflation equation, although we do not explicitly do so.
} 
equation model could then be used to detemine simultaneously the nominal interest rates and the rate of inflation, and the ex-post real interest rates can then be directly obtained from these two equations. $1 /$ Furthermore, if the inflation equation is used to determine the expected rate of inflation, then one can calculate the ex-ante real rate of interest.

To keep within the spirit of the model outlined here, the inflation equation specified should be general enough to allow both closed and open economy factors to play a role. In the extreme case of fully open economy, domestic monetary conditions will have no direct effect, and the inflation rate will depend solely on world inflation and the (actual) rate of devaluation. If, in addition, it is assumed that the expected real exchange rate will remain constant, the model will predict the equality of domestic and foreign real interest rates. On the other hand if the economy is completely closed, the domestic rate of inflation, as well as the nominal and real interest rates, will have no relation to their world counterparts. 2. Interest rates and liberalization

One of the limitations of the model presented in this paper is that it assumes a constant degree of openness of the financial sector in the country under study. However, a number of developing countries have recently gone through liberalization processes characterized by among other things, the relaxation or removal of existing capital controls. To the extent that these liberalization processes result in a higher 
degree of integration of the domestic and the world capital markets, the assumption of a constant $\psi$ is clearly inappropriate. $1 /$

There are several possible ways to proceed if the degree of openness is changing through time. The simplest way to model this would be to make the openness parameter a linear function of time as follows:

$$
\text { (15) } \psi_{t}=\psi_{0}+\psi_{1} t
$$

where $\psi_{0}$ is the constant part of the openness parameter and $t$ is a time trend. We would expect that $\psi_{1}>0$. If the level and intensity of capital controls vary smoothly and gradually over the period of study then equation (15) would be a reasonable approximation. One could use equation (15) to substitute for $\psi$ in the interest rate equation and then directly estimate the resulting reduced form. This simple form would obviously break down if the changes in capital controls were abrupt or erratic, and it would be necessary to consider other methods to formally capture the liberalization process.

Ideally, of course, one would wish to have some type of index that directly measured the degree of legal capital controls. It would then be possible to specify openness as a function of this index (C) as follows:

$$
\text { (16) } \psi_{t}=\psi_{0}+\psi_{1}(C)
$$

In the estimation process a number of possible alternative functional forms can be assumed. $\underline{2}$ / The main problem with this formulation, however, is obtaining data for the capital controls index (C). A possible $1 /$ It should also be noted that $\psi$ would depend on the interest rate chosen. For different interest rates one could easily have different values of $\psi$. We are indebted to Michael Mussa for this point.

2/ In formulating such types of equations one has to recognize that the endogenous variable $(\psi)$ is in fact bounded $(0,1)$. To properly take this into account the precise functional forms would be more complicated than the linear ones described here. 
way would be to construct a subjective measure from information that is actually available on the system of capital controls in the country in question. Alternatively, some type of proxy measuring the severity of capital controls can be used, and one candidate for this proxy might be the black market exchange premium. $1 /$

3. Expected devaluation and interest rate determination

Throughout the discussion in this paper no mention has been made to the way in which the expected rate of devaluation or the forward premium are determined. For purposes of the present exercise these were assumed to be exogenous. This is quite a restrictive assumption and a more realistic analysis would have to recognize that the expected exchange rate change is likely to be affected by movements in domestic interest rates, and more generally, by domestic monetary conditions. However, recognizing this issue and actually doing something about it are two quite different things, since in practice endogenizing the expected rate of devaluation or the forward premium has generally proved to be exceedingly difficult.

The way one would proceed will depend on the exchange rate system that the country in question has. If the country has a floating exchange rate, standard modern theories of exchange rate behavior can perhaps be used. Even so it should be recognized that this is no easy task since these models have not been particularly successful in predicting exchange

\footnotetext{
1/ A problen with the black market premiun is that it will tend to capture a variety of factors, including for example, the effect of actual and expected capital controls.
} 
rate movements. 1/ Under fixed rates the problem becomes even more complicated since the probability of an exchange rate crisis has then to be modelled explicitly. Some initial attempts have been made in this direction, but the modelling of exchange rate crises is still in its infancy. 2/ By and large it seems that the present state of the art of exchange rate modelling would preclude paying anything more than lip service to this particular issue.

\section{The role of currency substitution}

In combining the closed-economy version of the interest rate model with the open-economy formulation, the basic money demand function was left unchanged. This function, it will be recalled, allows for substitution to take place between money and domestic bonds and goods. While this is the appropriate specification in the case of a closed economy, it does prove to be somewhat restrictive once the possibility of substitution between domestic and foreign money, defined generally as currency substitution, is admitted. In other words one now has another asset in the system; i.e., foreign money, whose rate of return also has to be taken into account. Thus, in combining the two models one has to recognize that the demand for money function in an open economy could be different from the function relevant for a closed economy.

The importance of the currency substitution phenomenon has been documented in a number of studies. In contrast to earlier opinion,

\footnotetext{
1/ See Levich (1984) for a survey of such models for the major incustrial countries.

2/ See Blanco and Garber (1983) for a discussion of one such model. for the case of Mexico.
} 
which held that currency substitution was relevant only in countries with developed financial and capital markets, several writers have recently shown that currency substitution takes place frequently in developing countries as well. Furthermore, it has been found to occur in countries that differ considerably in levels of financial development, the degree of integration with the rest of the world, and types of exchange rate regimes and practices. Clearly currency substitution is a factor that should be explicitly taken into account in any realistic analysis.

How one would go out and model the effects of currency substitution is not, however, all that clear. The general consensus is that the principal determinant of currency substitution is the expected change in the exchange rate, although as pointed out in the previous sub-section (IV.3) there is a great deal of controversy on how this ought to be measured. other things equal, an expected depreciation of the domestic currency, for whatever reason, would cause residents to switch out of domestic money into foreign money, and vice versa. Once, however, the difficult problems associated with the choice of an appropriate empirical proxy for exchange rate expectations are surmoutned, the rest becomes relatively straightforward. The demand for (domestic) money function in an open economy could be re-specified as:

$$
\text { (5a) } \operatorname{logm}_{t}^{\mathrm{d}}=\alpha_{0}+\alpha_{1} \operatorname{logy}_{t}-\alpha_{2}\left(\rho+\pi_{t}^{e}\right)-\alpha_{3} \pi_{t}^{e}-\alpha_{4} \dot{e}_{t}
$$

The last term in this modified equation would then capture the effects of currency substitution. 
It should be mentioned that this type of formulation would not be applicable for the extreme cases of interest rate determination in a completely closed or completely open economy. In the former case the variable $\dot{e}$ would obviously not enter, while in the latter domestic monetary disequilibrium, and thus the demand for money, with or without currency substitution, does not matter. Equation (5a) would certainly be relevant in the intermediate case, which of course does correspond to the actual situation of most developing countries.

\section{v. Conclusions}

As more developing countries proceed to liberalize their domestic financial systems and remove restrictions on capital flows, the issue of interest rate determination becomes increasingly important. In particular, how interest rates can be expected to behave in the changed environment, and how they will respond to foreign influences and domestic policies, are questions policymakers in a number of developing countries have to consider. Only when interest rate behavior is well understood, will it be really possible to predict the effects of interest rate changes on key macroeconomic variables, such as savings, investment, the balance of payments, and economic growth, which are really the purposes for which presumably the liberalization policies were originally designed.

In this paper we derived a theoretically-consistent model that we believe can serve as a starting point for analyzing the process of interest rate determination in those developing countries that have undertaken financial reform policies. Although this model has a fairly simple structure it is nevertheless able to incorporate the principal determinants of interest rates, such as foreign interest rates, expected changes in 
exchange rates, and domestic monetary developments. One of the interesting characteristics of the model is that it is sufficiently general so as to be applicable to a variety of developing countries that differ widely in teris of the degree to which they are financially open. Indeed it is possible to empirically determine the degree of financial openness, defined both as the extent to which domestic interest rates are linked to foreign interest rates, as weil as the speed which they respond to changes in the latter, from the data for the individual country. This measure of "economic" openness may differ quite significantly from the "official" or "legal" degree of openness implied by the prevailing system of capital controls.

For illustrative purposes the model was applied to two countriesColombia and Singapore. These two countries are at quite different stages of financial development and thus are able to provide a useful first test of the general nature of the model. For example, Colombia still maintains restrictions on capital movements and only part of the financial sector can be characterized as free, while singapore is a highly open economy with a dynamic and sophisticated financial market that has close links with the major financial centers. The estimates confirmed our priors, in the sense that we found that both foreign and domestic factors were important in interest rate determination in the Colombian case, but that only foreign factors appeared to matter in the case of Singapore. It is also worth noting that our results indicated that Colombia is more open than suggested by the actual system of capital 
controls. In conclusion, while one should obviously be careful in generalizing from the results of only two countries, we nonetheless feel this model has considerable potential and can serve as a useful starting point for studying the behavior of interest rates in developing countries. 
A. Colombia $(1968-82)$

The basic sources for the data were Montes and Candelo (1982), Departamento Nacional de Planeacion (DNP), DANE, Boletin Mensual de Estadistica, and IMF, International Financial statistics (IFS).

The definitions of the variables and specific sources are as follows:

e = official buying rate for export receipts and capital inflows-Montes and Candelo (1982) and DNP; the variable $\dot{e}$ is defined as the percentage change in $e$.

$i=$ domestic interest rate; for 1968-69 this is the average rate on mortgage bills, and for 1970-82 it is the effective annual yield on 3-month Certificados de Abono Tributario--Montes and Candelo (1982) and DNP.

$i^{*}=3$-month U.S. Treasury Bill Rate-IFS.

$M=$ narrow (M1) money balances; for 1968-80 the data were obtained from Montes and Candelo (1982), and for the subsequent period 1981-82 from DNP.

$\mathrm{P}=$ consumer price index-DANE, Boletin Mensual de Estadistica; $\pi$ is defined as the percentage change in this index.

$\mathrm{y}=$ quarterly real GDP--Montes and Candelo (1982).

B. Singapore $(1976-83)$

The sources of the data are IMF, International Financial Statistics (IFS), and Monetary Authority of Singapore (MAS).

The definitions and specific sources are as follows:

$\dot{\mathrm{e}}=3$-month forward premium--MAS.

$i=3$-month interbank rate--MAS.

$i^{*}=3$-month Eurodollar rate--IFS.

$M=$ narrow (MI) money balances-IFS.

$\mathrm{P}=$ consumer price index-IFS; the variable $\pi$ is defined as the percentage change in this index.

$y=$ quarterly real GDP; the annual series were obtained from IFS and interpolated to a quarterly basis using an index of manufacturing production (IFS). 


\section{References}

Blanco, Herminio, and Peter M. Garber, "Recurrent Devaluation and Speculative Attacks on the Hexican Peso," (December 1983).

Blejer, Mario I., "Interest Rate Differentials and Exchange Risk: Recent Argentine Experience," IMF Staff Papers, 29, (June 1982), pp. $270-280$.

, and Mohsin-S. Khan, "The Foreign Exchange Market in a HighlyOpen Developing Economy: The Case of Singapore," Journal of Development Economics, 12 (February 1983), pp. 237-249.

, and Jose Gil Diaz, "On the Determination of the Real Interest Rate in a Small Open Economy: Domestic Versus External Factors," unpublished, (January 1984).

Cumby, Robert E, and Maurice Obstfeld, "A Note on Exchange-Rate Expectations and Nominal Interest Differentials: A Test of the Fisher Hypothesis," Journal of Finance, 36, (June 1981), pp. 697-703.

, and Mishkin, Frederic S., "The International Linkage of Real Interest Rates: The European-U.S. Connection," unpublished, (1984).

Darby, Michael R., "The Financial and Tax Effects of Monetary Policy on Interest Rates," Economic Inquiry, 13, (June 1975), pp. 266-276.

Diaz-Alejandro, Carlos F., Colombia, (New York: National Bureau of Economic Research, Columbia University Press), 1976.

, "Southern-Cone Stabilization Plans" In William R. Cline and Sidney Weintrub (eds.), Economic Stabilization in Developing Countries, (Washington, D.C.: Brookings Institution), 1981.

Dornbusch, Rudiger, "PPP Exchange-Rate Rules and Macroeconomic Stability," Journal of Political Economy, 90, (February 1982a), pp. 158-165.

, "Stabilization Policies in Developing Countries: What Have We Learned?" World Development, 10, (September 1982b), pp. 701-708.

Edwards, Sebastian, "Money, the Rate of Devaluation and Interest Rates in a Semi-Open Economy: Colombia 1968-1982," National Bureau of Economic Research Working Paper No. 1380; forthcoming Journal of Money, Credit and Banking (February 1985a).

, "Stabilization with Liberalization: An Evaluation of Ten Years of Chile's Experiment with Free Market Policies, 1973-1983," Economic Development and Cultural Change (forthcoming January 1985b). 
Fama, Eugene, F., "Short-Term Interest Rates as Predictors of Inflation," American Economic Review, 65, (June 1975), pp. 269-282.

Frenkel, Jacob A., and Richard M. Levich, "Covered Interest Arbitrage: Unexploited Profits?" Journal of Political Economy, 83, (April 1975), pp. 325-338.

, "Transactions Costs and Interest Arbitrage: Tranquil versus Turbulent Periods," Journal of Political Economy, 85, (December 1977), pp. 1209-1226

Fry, Maxwell J., "Models of Financially Repressed Developing Economies," World Development, 10, (September 1982), pp. 731-750.

Hanson, James and Jaime de Melo, "An Assessment of Reforms and Macroeconomic Developments in Uruguay: 1974-1982," unpublished, World Bank, 1984.

Harberger, Arnold C., "The Chilean Economy in the 1970s: Crisis, Stabilization, Liberalization, Reform," in Kar1 Brunner and Allan M. Meltzer (eds.), Economic Policy in a World of Change, CarnegieRochester Conference Series on Public Policy, 17, (Amsterdam), 1982, pp. 115-152.

Khan, Mohsin S., "The Dynamics of Money Demand and Monetary Policy in Singapore," in MAS, Papers on Monetary Economics (Singapore: Singapore University Press), 1981, pp. 46-76.

Lanyi, Anthony, and Rusdu Saracoglu, "The Importance of Interest Rates in Developing Economies," Finance and Development, 20, (June 1983), pp. 20-23.

Levich, Richard M., "Empirical Studies of Exchange Rates: Price Behavior, Rate Determination and Market Efficiency," in Peter B. Kenen and Ronald W. Jones (eds.), Handbook of International Economics, (Amsterdam: North-Holland), forthcoming 1984.

Lizondo, Jose Saul, "Interest Differential and Covered Arbitrage," in P. Aspe, R. Dornbusch, and M. Obstfeld (eds.), Financial Policies and the World Capital Market (Chicago: University of Chicago Press), 1983 , pp. 221-240.

Makin, John H., "Effects of Inflation Control Programs on Expected Real Interest Rates," IMF Staff Papers, 29, (June 1982), pp. 204-232.

Mathieson, Donald J., "Inflation, Interest Rates, and the Balance of Payments During a Financial Reform: The Case of Argentina," World Development, 10, (September 1982), pp. 813-828. 
"Estimating Models of Financial Market Behavior During Periods of Extensive Structural Reform: The Experience of Chile," IMF Staff Papers, 30, (June 1983), pp. 350-393.

McKinnon, Ronald I., Money and Capital in Economic Development, (Washington, D.C.: The Brookings Institution), 1973.

Melvin, Michael, "The Vanishing Liquidity Effect of Money on Interest Rates: Analysis and Implications for Policy," Economic Inquiry, 21, (April 1983), pp. 188-202.

Montes, Gabriel and Candelo, Ricardo, "El Enfoque Monetario de la Balanza de Pagos: El Caso de Colombia 1968-1980," Revista de Planeacion y Desarro11o, 7, (Mayo-Agosto 1982), pp. $\frac{\text {. }}{11-40}$.

Mundell, Robert A., "Inflation and Real Interest," Journal of Political Economy, 71, (June 1963), pp. 280-283.

Sjaastad, Larry A., "Failure of Economic Liberalism in the Cone of Latin America," The World Economy, (March 1983), pp. 5-26.

Tanzi, Vito, "Inflation, Indexation and Interest Income Taxation," Banco Nazionale del Lavoro Ouarterly Review, 29, (March 1976), pp. $64-76$.

, "Inflationary Expectations, Economic Activity, Taxes, and Interest Rates," American Economic Review, 70, (March 1980), pp. $12-21$.

Townsend, Robert $\mathrm{M} .$, "Financial Structure and Economic Activity," American Economic Review, Vol. 73, (December 1983), pp. 895-911.

Wiesner, Eduardo, "Devaluacion y Mecanismo de Ajuste en Colombia," in Politica Economica Externa Colombiana (Bogota: Asociacion Bancaria de Colombia), 1978.

Zahler, Robert, "Recent Southern Cone Liberalization Reforms and Stabilization Policies: The Chilean Case, 1974-1982," Journal of Interamerican Studies and World Affairs, (November 1983), pp. 445-76. 